九州大学学術情報リポジトリ

Kyushu University Institutional Repository

\title{
Rapid Extraction-HPLC as a Tool for Presumptive Identification of Burkholderia gladioli, B. glumae and B. plantarii, Causal Agents of Various Rice Diseases
}

Matsuyama, Nobuaki

Laboratory of Plant Pathology, Faculty of Agriculture, Kyushu University

Ueda, Yasuko

Laboratory of Plant Pathology, Faculty of Agriculture, Kyushu University

I i yama, Kazuhiro

Laboratory of Plant Pathology, Faculty of Agriculture, Kyushu University

Furuya, Naruto

Laboratory of Plant Pathology, Faculty of Agriculture, Kyushu University

他

https://doi.org/10.5109/24212

出版情報 : 九州大学大学院農学研究院紀要. 42 (3/4)，pp. 265-272，1998-03. Kyushu University バージョン：

権利関係 : 


\title{
Rapid Extraction-HPLC as a Tool for Presumptive Identification of Burkholderia gladioli, B. glumae and B. plantarii, Causal Agents of Various Rice Diseases
}

\author{
Nobuaki Matsuyama, Yasuko Ueda, Kazuhiro Iiyama, Naruto Furuya, \\ Hiroyuki Ura, Abu Ashraf Khan and Masaru Matsumoto
}

\author{
Laboratory of Plant Pathology, Faculty of Agriculture, \\ Kyushu University, Fukuoka 812-8581, Japan \\ (Received October 8, 1997 and accepted December 3, 1997)
}

\begin{abstract}
Rapid extraction-HPLC was performed to estimate its usefulness for presumptive identification of Burkholderia gladioli, B. glumae and B. plantarii. On HPLC chromatograms of 12 isolates of $B$. gladioli, a distinct peak appeared at Rt $6.2 \mathrm{~min}$ without exception. This peak was absent on the chromatograms for 18 isolates of $B$. glumae and 5 isolates of $B$. plantarii tested. Benchmark peak at Rt $3.2 \mathrm{~min}$ was observed on the chromatogram of $B$. plantarii. Together with the direct colony TLC method, this simplified HPLC analysis will be useful for identification of phytopathogenic bacteria.
\end{abstract}

\section{INTRODUCTION}

In general, the morphological, biochemical, serological and pathological tests are indispensable for the identification of phytopathogenic bacteria (Shaad, N. W., 2nd ed., 1988). However, it is time-consuming and needs much experience. Therefore, development of rapid and novel methods, even though presumptive, has long been required. Previously, the authors reported the usefulness of the direct colony TLC method which was originally invented for rapid identification of lipids (Matsuyama et al., 1986, 1987). This method was successfully applied for rapid identification of phytopathogenic bacteria (Matsuyama et al., 1993a, b, c, d; Matsuyama and Furuya, 1993e; Matsuyama, 1995a, b). High reproducibility for results, easiness and rapidity for performance indicated clearly its practical usefulness of this method for rapid diagnosis.

However, in the cases of Burkholderia gladioli, B. glumae and B. plantarii, causal agents of rice diseases (Ura et al., 1996) and recognized as being closely related, TLC chromatograms are similar and not so easy to discriminate. To differentiate these species the rapid extraction-HPLC analysis which was invented by one of the authors (Matsuyama, 1995) was applied. A part of results was abstracted (Matsuyama et al., 1996) and detail was presented in this report.

\section{MATERIALS AND METHODS}

\section{Bacterial strains}

Twelve isolates of Burkholderia gladioli (Pseudomonas gladioli), 18 isolates of $B$. glumae ( $P$. glumae) and 5 isolates of $B$. plantarii ( $P$. plantarii) were used in this experiment. The type cultures of these three species were obtained from ATCC, MAFF, 
JCM and Dr. Azegami. Sources and origins were presented in Table 1.

Table 1. Phytopathogenic bacteria tested.

\begin{tabular}{|c|c|c|}
\hline Strains & Origins & Sources \\
\hline \multicolumn{3}{|c|}{$\begin{array}{l}\text { Burkholderia gladioli } \\
\text { pv. gladioli }\end{array}$} \\
\hline ATCC $10248^{\top}$ & Gladiolus & ATCC \\
\hline MAFF 301064 & Freesia & NIAR \\
\hline MAFF 301580 & Dendrobium & " \\
\hline MAFF 302515 & Tulip & " \\
\hline MAFF 302537 & Onion & $"$ \\
\hline MAFF 302544 & Rice & " \\
\hline 1064 & Freesia & NIAS \\
\hline 1065 & " & " \\
\hline E-14 & Rice & AKU \\
\hline \multicolumn{3}{|c|}{ B. gladioli pv. unidentified } \\
\hline MAFF 302409 & Adzuki bean & NIAR \\
\hline MAFF 302418 & Green gram & " \\
\hline MAFF 302424 & Cymbidium & " \\
\hline \multicolumn{3}{|l|}{ B. glumae } \\
\hline MAFF $301169^{\text {T }}$ & Rice grain & NIAR \\
\hline $\mathrm{Ku} 8104$ & " & AKU \\
\hline Ku 8105 & " & $"$ \\
\hline Ku 8112 & " & " \\
\hline Ku 8114 & " & " \\
\hline 8012 & " & KNAES \\
\hline 8015 & " & " \\
\hline 8020 & " & " \\
\hline N7401 & Rice seedling & NIAS \\
\hline N7501 & " & " \\
\hline N7503 & " & $"$ \\
\hline N7504 & " & $"$ \\
\hline N7505 & " & " \\
\hline 2 & Rice grain & KNAES \\
\hline III & " & " \\
\hline 805 & Unknown & NIAS \\
\hline AZ8224 & Rice grain & Dr. Azegami \\
\hline AZ84448 & " & " \\
\hline \multicolumn{3}{|l|}{ B. plantarii } \\
\hline AZ8201 & Rice & Dr. Azegami \\
\hline JCM $5492^{\mathrm{T}}$ & " & JCM \\
\hline MAFF301723 ${ }^{\mathrm{T}}$ & " & Dr. Azegami \\
\hline MAFF302484 & " & NIAR \\
\hline MAFF302387 & " & " \\
\hline \multicolumn{3}{|l|}{$\begin{array}{l}\text { Erwinia carotovora } \\
\text { subsp. carotovora }\end{array}$} \\
\hline
\end{tabular}

Abbreviations: ATCC; American Type Culture Collection, USA. NIAR; National Institute of Agricultural Resources, Tsukuba 305, Japan. NIAS: National Institute of Agricultural Sciences, Tokyo, Japan (This institute was consolidated to NIAR and National Institute of Agro-Environmental Sciences, NIAES). KNAES: Kyushu National Agricultural Experiment Station, Kumamoto 861-11, Japan. AKU; Faculty of Agriculture, Kyushu University, Fukuoka 812-81, Japan. JCM: Japan Collection of Microorganisms (RIKEN), Wako, Saitama 351-01, Japan.

Type Cultures of Burkholderia gladioli, B. glumae and B. plantarii represented as ${ }^{\top}$ at the shoulder of strain's numbers. 


\section{Direct colony TLC}

Isolates were cultured on a slant of King's B medium (Eiken Co.) at $30^{\circ} \mathrm{C}$ for 3 days. One loop bacterial cells was applied directly on the origin of silica gel G (Si60) TLC plate (Merck Co.). After complete drying in an automatic desiccator and/or with a hair drier, the TLC plate was developed in a development glass chamber for 10 min with a chloroform-methanol solution $(2: 1, \mathrm{v} / \mathrm{v})$ in an incubator at $25^{\circ} \mathrm{C}$. The plate was taken out, dried completely and the bacterial cells were scraped off. The plate was developed in the same direction with a chloroform-methanol-water solution $(60: 25: 4, \mathrm{v} / \mathrm{v} / \mathrm{v})$ in an incubator at $25^{\circ} \mathrm{C}$ for $1.5 \mathrm{hr}$. After development the plate was dried and the spots were detected by spraying with ninhydrin (Ninhydrin spray, Kanto Chem. Co.) and heating at $100^{\circ} \mathrm{C}$ for $10 \mathrm{~min}$. The chromatogram obtained was recorded by a sensitively adjusted photocopy (Canon FC-3 I ) or by a computer (Photoshop 3.0J, Adobe Co.).

\section{Extraction of whole-cellular bacterial lipids}

One loop bacterial cells which were cultured at $30^{\circ} \mathrm{C}$ for 3 days on slants of King's B medium (Eiken Co.) was applied on the bottom of a small glass-vial and $0.5 \mathrm{ml}$ of a chloroform-methanol solution $(2: 1, \mathrm{v} / \mathrm{v})$ was added. Bacterial cells were suspended in the solution by stirring with the loop and kept for $60 \mathrm{~min}$ at room temperature. The suspension was transferred into a weighing vessel $(3 \mathrm{~cm}$ in diameter) and the solvent evaporated. One $\mathrm{ml}$ of $80 \%$ aqueous methanol solution was added and the extract was dissolved by stirring and rubbing, carefully, the inner-surface of vessel with a tip of plastic hypodermic-syringe ( $1 \mathrm{ml}$, Termo Co.). Suspensions were passed through a $0.2 \mu \mathrm{m}$ filter (PTFE, Advantec Co.).

\section{HPLC analysis}

Twenty $\mu \mathrm{l}$ of the filtrate were applied to a HPLC (Shimadzu LC system, LC-9A, SPD10A, Chromatopac C-R5A, DGU-10A) equipped with a reversed-phase column (Totally porous, spherical particle, silica gel; $5 \mu \mathrm{m}$ particle diameter, $120 \AA$ pore diameter, octadecyl, Shim-pack HRC-ODS $6 \times 150 \mathrm{~mm}$ ). 'Elution was conducted with $80 \%$ aqueous methanol solution at a flow rate of $1 \mathrm{ml} / \mathrm{min}$. Peaks were detected with a UV detector at $210 \mathrm{~nm}$. Experiments were repeated five times, and the results were confirmed.

\section{RESULTS AND DISCUSSION}

The direct colony TLC is quite useful for rapid differentiation of various phytopathogenic bacteria within $2.5 \mathrm{hrs}$ (Matsuyama et al., $1993 \mathrm{a}, \mathrm{b}, \mathrm{c}, \mathrm{d}$; Matsuyama and Furuya, 1993e; Matsuyama, 1995 a, b; Matsuyama et al., 1996) except for the cases of interspecific differentiation of Xanthomonas and differentiation of Pseudomonas syringae pathovars.

As can be seen in Figs. 1, 2, the chromatografic profiles are different at generic and sometimes at specific level. In the case of the new genus Burkholderia (Pseudomonas, rRNA homology group II), the TLC chromatograms were distinctly different for most of the species (Matsuyama, 1995b). However, the TLC chromatograms of $B$. gladioli, $B$. glumae and $B$. plantarii, which are causal agents of various rice diseases (Kurita and Tabei, 1967; Uematsu et al., 1976; Azegami et al., 1983; Yasunaga et al., 1986; Ura et al., 


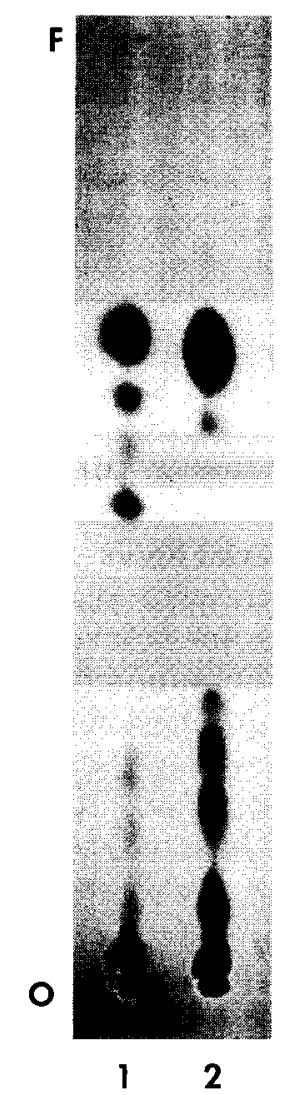

Fig. 1. Comparison of chromatograms of the direct colony TLC for Burkholderia gladioli pv. gladioli and Erwinia carotovora subsp. carotovora.

Lane 1; Burkholderia gladioli pv. gladioli (ATCC10248'), Lane 2; Erwinia carotovora subsp. carotovora (ATCC 15713').

$\mathrm{O}$; origin, $\mathrm{F}$; front

1996), are similar (Fig. 2). Recently, one of authors (Matsuyama, 1995a) presented a novel identification method using HPLC. This technique is similar with the direct colony TLC for extraction of lipids, in principle. In the direct colony TLC, extraction of lipids is carried out on the silica gel (Si60) TLC plate. In the case of the rapid extraction-HPLC, this lipid extraction is conducted in chloroform-methanol solution $(2: 1, \mathrm{v} / \mathrm{v})$ in a capped small glass-vial. The separation of extracted lipids was conducted with a reversed-phase HPLC and polar solvent system. Distinct differences were observed among $B$. gladioli, $B$. glumae and $B$. plantarii for HPLC chromatograms. The benchmark peak appeared at retention time (Rt) $6.2 \mathrm{~min}$ on the chromatogram of $B$. gladioli (Fig. 3). Whereas no peak was detected at the corresponding time in the cases of B. glumae and B. plantarii (Figs. 4, 5). This diversity among species was observed without any exception. On the chromatogram of $B$. plantarii benchmark peak appeared at Rt $3.2 \mathrm{~min}$ and absent on those of other two species (Figs. 3, 4,5). This marker peak of $B$. plantarii was more 


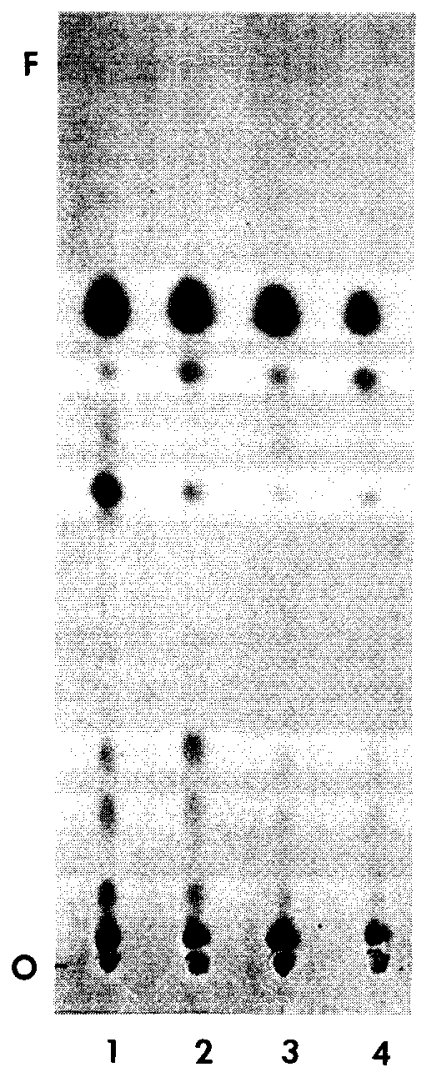

Fig. 2. Comparison of chromatograms of the direct colony TLC for B. plantarii, $B$. glumae and B. gladioli pv. gladioli.

Lane $1 ;$ B. plantarii (JCM5492 ), Lane 2; B. glumae (MAFF301169'), Lane $3 ;$ B. gladioli pv. gladioli (MAFF301580), Lane $4 ;$ B. gladioli pv. gladioli $\left(\mathrm{ATCC} 10248^{\mathrm{T}}\right.$ )

$\mathrm{O}$; origin, $\mathrm{F}$; front

distinctly detected when bacteria was cultured on YPDA (Yeast extract-PeptoneDextrose-Agar) and AFG (glucose and Fe amended Ayers medium). The substance(s) appeared at Rt $3.2 \mathrm{~min}$ on the chromatogram of $B$. plantarii could be relative of tropolone (Azegami et al., 1987). The identification of the substances appeared at Rt 6.2 and $3.2 \mathrm{~min}$ is the subject for future study. In the rapid extraction-HPLC, like the direct colony TLC, lipid extraction was performed under mild condition and each benchmark substance could be extracted at the intact state. This method is easy to perform and the result is obtained within $100 \mathrm{~min}$. Together with the direct colony TLC analysis, this rapid extraction-HPLC analysis has practical use for rapid diagnosis of phytopathogenic diseases. 

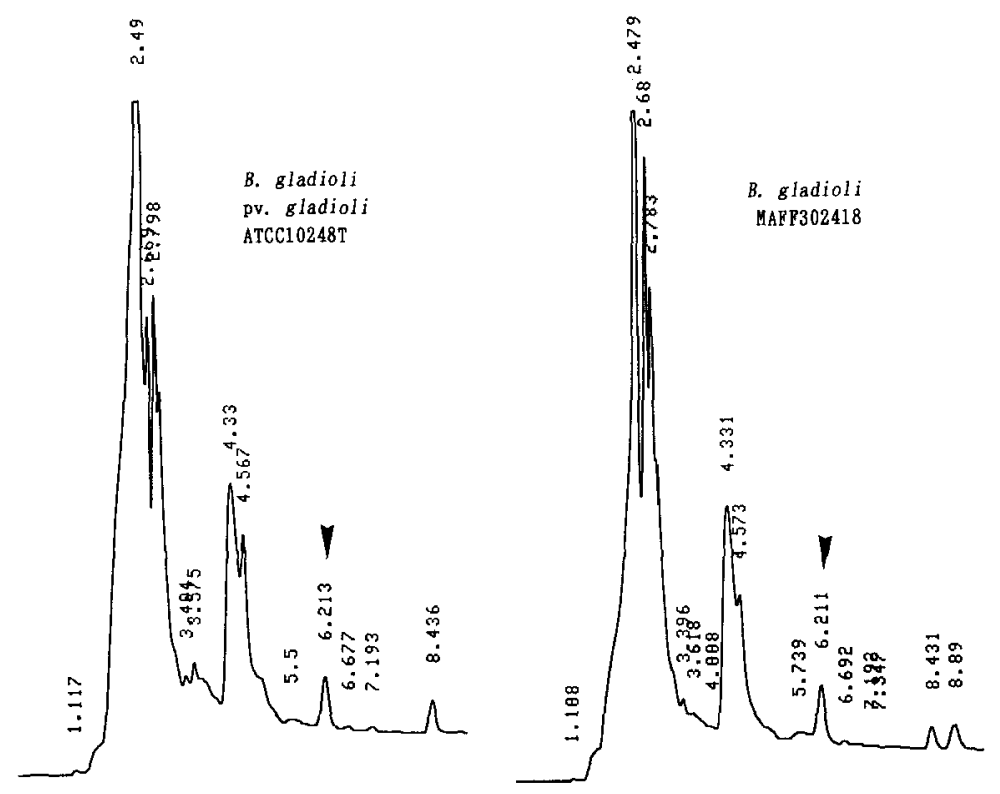

Fig. 3. Rapid extraction-HPLC chromatograms of $B$. gladioli. Arrow heads indicate the benchmark peak at Rt $6.2 \mathrm{~min}$. This benchmark appeared on the chromatograms of $B$. gladioli without exception.

Left; ATCC10248 , Right; MAFF302418

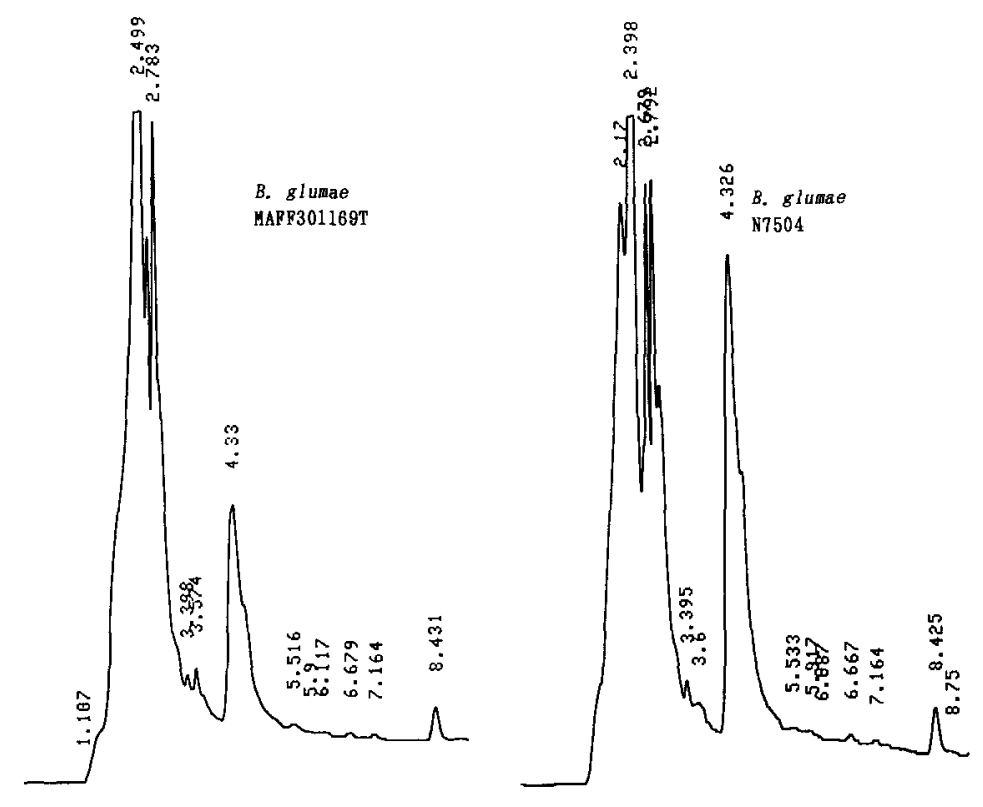

Fig. 4. Rapid extraction-HPLC chromatograms of B. glumae. Left; MAFF301169 , Right; N7504 


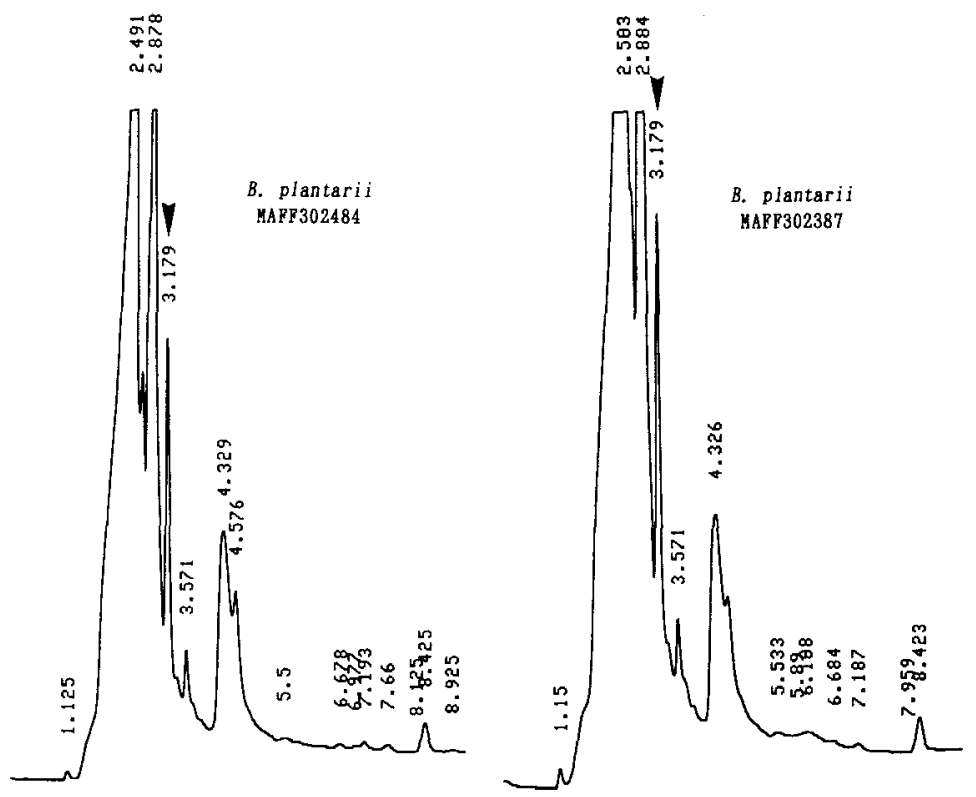

Fig. 5. Rapid extraction-HPLC chromatograms of B. plantarii. Arrow heads indicate the benchmark peak at Rt $3.2 \mathrm{~min}$. Left; MAFF302484, Right; MAFF302387

\section{ACKNOWLEDGEMENT}

The authors are indebted to the staff of the Institute of Biological Resources, Ministry of Agriculture, Forestry and Fishery and Dr. K. Azegami for their kind supply of the bacterial strains

\section{REFERENCES}

Azegami, K., K. Nishiyama, Y. Watanabe, I. Kadota, A. Ohuchi and C. Fukazawa 1987 Pseudomonas plantarii sp. nov., the causal agent of rice seedling blight. Int. J. Syst. Bacteriol., 37(2): 144-152

Goto, K. and K. Ohata 1956 Newly-found causal bacteria of rice diseases. Ann. Phytopath. Soc. Japan, 21(1): 46-47 (Abstract)

Kurita, T. and H. Tabei 1967 Causal bacterium of rice grain rot. Ann. Phytopath. Soc. Japan, 41(3): 111 (Abstract)

Matsuyama, N. 1993a Rapid identification of phytopathogenic bacteria by the direct colony thin-layer chromatography. Proc. 6 th International Congress of Plant Pathology, Montreal, Canada, p44

Matsuyama, N., Ismail Hossain Mian, Abdul Mannan Akanda and N. Furuya 1993b Application of the direct colony TLC method for identification of phytopathogenic bacteria. J. Fac. Agr. Kyushu Univ., $\mathbf{3 7}(\mathbf{3}, \mathbf{4})$ : $281-285$

Matsuyama, N., Ismail Hossain Mian, Abdul Mannan Akanda and N. Furuya 1993c Rapid identification of phytopathogenic bacteria by the direct colony thin-layer chromatography (1). Proc. Assoc. Pl. Prot. Kyushu, 39: 60-64 
Matsuyama, N., Ismail Hossain Mian, Abdul Mannan Akanda and N. Furuya 1993d Comparative studies on thin-layer chromatograms of lipids from various phytopathogenic bacteria. Ann. Phytopath. Soc. Japan, 59: 528-534

Matsuyama, N. and N. Furuya 1993e Application of the direct colony TLC for identification of phytopathogenic bacteria (II) Chromatographic profile of Erwinia and Pseudomonas spp. J. Fac. Agr. Kyushu Univ., 38(1, 2): 89-95.

Matsuyama, N. 1995a Trials for rapid identification of phytopathogenic bacteria by HPLC and the direct colony TLC. J. Fac. Agr. Kyushu Univ., 40(1, 2): 87-91

Matsuyama, N. 1995b Application of the direct colony TLC for identification of phytopathogenic bacteria (III). Distinction of the pseudomonads in the rRNA-homology group II (Burkholderia spp.). J. Fac. Agr. Kyushu Univ., 40(1, 2): 189-196

Matsuyama, N., Y. Ueda and K. Iiyama 1996 Trial of rapid identification of phytopathogenic bacteria by HPLC (2) Chromatograms of pseudomonads Ann. Phytopath. Soc. Japan, 62(3): 304-305

Matsuyama, T., M. Sogawa, K. Kaneda and I. Yano 1986 Rapid detection and identification of bacterial lipids by direct colony thin-layer chromatography. Proc. of 23 rd international symposium of advances in chromatography, Chiba, Japan, pp127-128

Matsuyama, T., M. Sogawa and I. Yano 1987 Direct colony thin-layer chromatography and rapid characterization of Serratia marcescens mutants defective in production of wetting agents. Appl. Environ. Microbiol., 53: 1186-1188

Uematsu, T., D. Yoshimura, K. Nishiyama, T. Ibaraki, H. Fujii 1976 Occurrence of bacterial seedling rot in nursery flat, caused by grain rot bacterium Pseudomonas glumae. Ann. Phytopath. Soc. Japan, 42(3): $310-312$

Ura, Y., K. Iiyama, N. Furuya and N. Matsuyama 1996 Properties of the bacteria isolated from rice plants with leaf-sheath browning and grain rot. Ann. Phytopath. Soc. Japan, 62(6): 640 (Abstract)

Yasunaga, T., T. Aoi, and Y. Shigematsu 1986 Occurrence of leaf-sheath browning of rice plants caused by bacterial grain rot of rice. Proc. Assoc. Protec. Shikoku, 21: 1-11 